\title{
Interactive comment on "Contribution of HONO to the atmospheric oxidation capacity in an industrial zone in the Yangtze River Delta region of China" by Jun Zheng et al.
}

\section{Anonymous Referee \#1}

Received and published: 11 January 2020

The comment was uploaded in the form of a supplement:

https://www.atmos-chem-phys-discuss.net/acp-2019-944/acp-2019-944-RC3-

supplement.pdf

Interactive comment on Atmos. Chem. Phys. Discuss., https://doi.org/10.5194/acp-2019-944, 2019. 